\title{
MOJOPURA WETAN, DESA PENYEBERANGAN DI DAERAH ALIRAN SUNGAI (DAS) BENGAWAN SOLO PADA MASA MAJAPAHIT?
}

\author{
T.M. Hari Lelono \\ (Balai Arkeologi Yogyakarta)
}

\begin{abstract}
Majapahit is a powerful kingdom which ruled Java from $12^{\text {th }}$ to $15^{\text {th }}$ century A.D. The kingdom was well known as the center of Javanese civilization with a tremendous influential power throughout the archipelago. Its capital was found in an area which had long been assumed as located in Trowulan District of Mojokerto Region in East Java. Archaeologists had long been assumed that the potential main access for entering the area were roads as well as rivers with Bengawan Solo as the most important one. Some old Javanese inscriptions mentioned the crossing-through villages lying over the river's edge which among them were Madanten, Wringin Wok and Bajrapura. Those village names could still easily be found until today, located over the edge of Bengawan Solo River in Gresik District. Mojopura Wetan is believed as an ancient village as mentioned in the inscription, identical to Bajrapura. Beside located close to Bengawan Solo, in the village was also found Hindu and Buddha statues. At present in the village could still be found the activity of local people using small boat to cross the river.
\end{abstract}

Key words: Bengawan Solo, Mojopura Wetan, Majapahit, arkeologi dan desa penyeberangan.

\section{PENDAHULUAN}

Bengawan Solo dan Kali Brantas adalah dua sungai besar yang bermuara di Pantai Utara Jawa Timur, masing-masing di Kabupaten Gresik dan Surabaya. Kedua sungai tersebut berhulu di pedalaman Pulau Jawa. Bengawan Solo berhulu di wilayah Surakarta, tepatnya di Dlepih Kayangan, Kabupaten Wonogiri, Jawa Tengah. Dlepih Kayangan tidak saja dikenal sebagai hulu Bengawan Solo, tetapi juga tempat keramat bagi masyarakat Jawa saat ini. Mereka percaya bahwa Panembahan Senapati, sebagai pendiri dinasti Mataram Islam, pernah bertapa untuk mendapatkan wahyu dan petunjuk dari Yang Mahakuasa untuk mendirikan kerajaan. Dari sumber air di Dlepih Kayangan ini, air Bengawan Solo mengalir ke dataran yang lebih rendah di sebelah utaranya untuk bermuara di Pantai Utara Kabupaten Gresik. 
Bengawan Solo merupakan salah satu sungai yang terkenal di Jawa karena cukup lebar, panjang, dan dalam, tetapi arusnya cukup tenang, sehingga dapat dilayari baik dari arah muara ke hulu, atau sebaliknya. Dengan kondisi tersebut, bukan hal yang mustahil, jika dari dulu sungai ini menjadi sarana transportasi yang penting untuk mengangkut barang-barang niaga (perdagangan) dan manusia, meskipun pada masa kini peran Bengawan Solo sebagai jalur transportasi dari daerah muara ke hulu dapat dikatakan hampir tidak ada lagi. Mungkin hal ini disebabkan karena jalur transportasi darat lebih

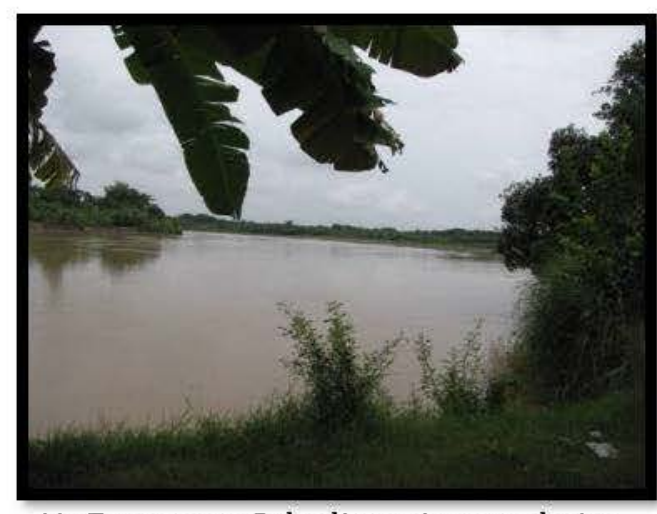

Air Bengawan Solo di musim penghujan Sumber: dok.Balar Yogya mudah dan cepat.

Di daerah DAS Bengawan Solo seperti di Blora, Bojonegoro, Lamongan dan Gresik, hingga kini masih terdapat desa-desa penyeberangan sungai. Bermacam istilah yang digunakan oleh masyarakat untuk menyebut tempat penyeberangan, di antaranya tambangan, tambang dan sebrangan. Kenyataan ini mengingatkan kita pada beberapa prasasti masa Majapahit yang menyebutkan nama desadesa tempat penyeberangan. Keberadaan desa-desa penyeberangan tersebut sekarang memang agak sulit untuk diketahui letaknya. Salah satu penyebabnya adalah terjadinya perubahan alur-alur sungai, sebagai akibat dari proses sedimentasi akibat banjir yang sering terjadi, sehingga letak desanya pun bergeser atau berpindah Selain itu, sering pula terjadi perubahan pengucapan nama, pergantian nama, dan munculnya desa-desa baru. Meskipun demikian, upaya untuk melacak desa-desa penyeberangan masih dapat dilakukan, antara lain dengan mencari tinggalan arkeologis yang mungkin masih dapat ditemukan di tempat-tempat tersebut.

Sulitnya pelacakan desa-desa kuna yang pernah menjadi tempat penyeberangan pada masa Majapahit merupakan suatu tantangan yang mendorong dilakukannya penelitian ini. Penemuan desa-desa penyeberangan itu sangat berpotensi memberikan gambaran yang lebih nyata tentang peran desa-desa tersebut dan bagaimana aktivitas penyebarangan yang pernah dilakukan oleh masyarakat Jawa kuna. Penelitian dilakukan dengan melacak keberadaan desa-desa penyeberangan berdasarkan pada sumber-sumber tertulis, berupa prasasti. Selanjutnya, nama-nama desa tersebut dilacak di daerah aliran sungai, dalam hal ini Bengawan Solo, dengan memanfaatkan keterangan dan informasi dari masyarakat. Di desa-desa yang namanya mirip dengan nama dalam prasasti dilakukan survei untuk mengetahui kemungkinan adanya tinggalan-tinggalan arkeologis yang dapat mendukung keberadaan desa itu sebagai desa kuna. 
Ditemukannya bukti arkeologis, ternyata belum menjawab tentang aspek kehidupan masyarakat pada masa Jawa kuna. Karena itu, untuk dapat merekonstruksi cara-cara penyeberangan dapat dilakukan melalui analogi etnografi, yaitu dengan mengamati kehidupan masyarakat sekarang, khususnya tukang sabrang yang masih ada di beberapa desa di DAS Bengawan Solo. Analogi etnografi ini lebih didasarkan pada perbandingan umum yang menganggap bahwa hubungan antara budaya arkeologi yang pendukungnya telah punah dengan budaya yang masih berlangsung, pada hakekatnya adalah hubungan bentuk, sehingga tidak selalu memiliki kaitan historis, ruang, dan waktu.

Namun demikian, pendekatan yang akan digunakan adalah kesinambungan budaya, mengingat bahwa daerah tersebut telah disebutsebut di dalam sumber prasasti Masa Majaphit yang menyebutkan namanama desa tempat penyeberangan. Prinsip kesinambungan budaya akan dapat lebih dimengerti apabila dikaitkan dengan pemahaman tentang hakekat kebudayaan itu sendiri. Menurut Hans Daeng (2005: 45): kebudayaan merupakan pola-pola pemikiran serta tindakan tertentu yang terungkap dalam aktivitas, sehingga pada hakekatnya kebudayaan itu sesuai dengan apa yang dikatakan Ashley Montagu, yaitu a way of life atau cara hidup tertentu, yang memancarkan identitas tertentu pula pada suatu bangsa. Dapat juga dikemukakan, kebudayaan adalah keseluruhan proses hasil perkembangan manusia yang disalurkan dari generasi ke generasi untuk kehidupan manusiawi yang lebih baik. Pendapat tersebut, semakin memperjelas bahwa kebudayaan yang berkembang saat ini merupakan kelanjutan dari kebudayaan masa lalu. Oleh karena itu, studi etnoarkeologi akan relevan dilakukan jika antara data etnografi dan data arkeologi memiliki persamaan atau kesinambungan sejarah.

\section{DESA MOJOPURA WETAN DAN TINGGALAN ARKEOLOGIS}

Berdasarkan sumber-sumber tertulis diketahui bahwa di sepanjang tepian sungai-sungai besar, terdapat desa-desa tempat penyeberangan. Disebutkan pula, beberapa desa penyeberangan itu dibebaskan dari pajak, karena jasa-jasa para tukang perahu (tukang satang) yang bertugas menyeberangkan orang maupun barang. Desa-desa tersebut memang sudah sangat sulit dilacak keberadaannya, tetapi ada beberapa desa masih mungkin dapat dikenali berdasarkan pelacakan nama-nama desa (toponim) sekarang. Dalam prasasti penyeberangan (Ferry Charter) berangka tahun 1358 Saka, disebutkan setidaknya 77 nama desa penyeberangan atau penambangan, antara lain tiga desa yang menjadi bagian penelitian ini.

Prasasti berangka tahun 1358 tersebut pada bagian

Plate 5, recto menyebutkan 
4. muwah prakāraning naditira pradeça sthānaning anāmbangi i madantěn, i waringin wok, i bajrapura,

(Pigeaud, 1960: 110).

Nama-nama Madantěn, Wringin Wok dan Bajrapura kemungkinannya sampai sekarang masih terabadikan menjadi nama tiga desa di Kecamatan Bungah, Gresik, yang semuanya terletak di dekat muara Bengawan Solo lama. Madantěn mungkin sekali menjadi Desa Bedanten sekarang. Bukti arkeologis yang terdapat di desa ini antara lain adalah makam tua masa Islam yang dianggap sebagai cikal bakal desa. Tokoh yang dimakamkan bemama Sayyid Khusaini. Bentuk makam berupa empat persegi dengan ukuran panjang empat meter dan terbuat dari bahan batu putih. Pada sisi bagian dalam batu nisan yang berukuran tinggi $50 \mathrm{~cm}$ dan lebar $45 \mathrm{~cm}$, terdapat pahatan berupa tulisan Arab yang belum terbaca. Makam tersebut masih di keramatkan penduduk dan pada waktu tertentu banyak dikunjungi orang untuk melakukan ziarah.

Desa Kali Wot (Wringin Wok) juga terletak di tepi utara Bengawan Solo. Namanya masih tetap menjadi nama desa sekarang. Dahulu di desa ini terdapat tambangan, tetapi sesuai dengan berjalannya waktu dan perkembangan pembangunan jalan raya dan jembatan baru, aktivitas tersebut sudah hilang. Sejauh ini belum dapat ditemukan bukti-bukti arkeologis yang dapat mendukung keberadaan desa ini sebagai desa kuna.

Yang paling menarik adalah keberadaan Desa Mojopuro Wetan di Kecamatan Bungah, tidak jauh dari kedua desa yang disebut terdahulu. Letak topografis ketiga desa ini saling berdekatan, hanya dalam radius tujuh kilometer. Selain itu, menurut keterangan ketiganya merupakan desa tambangan (penyeberangan). Nama desa Mojopuro sendiri mungkin sekali berasal dari nama desa Bajrapura yang disebut dalam prasasti berangka tahun 1358 Saka. Desa agraris yang subur dan terletak di sisi utara Bengawan Solo ini, menyimpan potensi arkeologis yang cukup besar dan perlu untuk ditelaah lebih lanjut keterkaitannya dan perannya pada masa Majapahit. Apalagi, hingga kini masyarakat setempat, utamanya generasi tua, masih menganggap desa yang sering hanya disebut Jepuro ini sebagai 'pintu masuk' ke Majapahit.

Hal yang sangat menarik di desa Mojopuro Wetan ditemukan beberapa tinggalan arkeologis berupa dua arca Dwarapala (gupala) dan satu arca Budha dalam posisi tergolek di permukaan tanah di bawah gerumbul pohon bambu.

1. Arca Dwarapala pertama masih relatif utuh, sayangnya pada bagian wajah (pipi dan hidung) rusak. Bagian anggota badan secara keseluruhan masih utuh, bahkan dapat diidentifikasi hiasan yang dikenakan; Arca ini berukuran dengan tinggi sekitar tiga meter, lebar satu meter, serta tebal setengah meter. Arca yang cukup besar ini menunjukkan ciri-ciri ikonografi sebagai berikut.

- Tangan kiri memegang gada. 
- Pada bagian pergelangan kaki dan tangan berhiaskan upawita berupa ular.

- Perhiasan lainnya berupa untaian kelopak bunga dan tengkorak manusia yang disebut hara, kuchabanda serta kundala

- sedangkan wastra dikenakan dari bagian pinggang hingga kaki.

2. Arca dwarapala dalam kondisi sudah rusak hanya tersisa bagian badan dan kaki.

3. Arca Budha dengan kondisi masih utuh dengan tinggi dua meter dan lebar satu meter. Sayang sekali, pada saat ke lokasi arca tersebut sudah lama hilang, dan tidak ada seorangpun yang mengetahui dan dapat menjelaskan ciri-ciri arca selengkapnya, seperti, bentuk dan model asesoris yang dikenakan arca.

Keberadaan ketiga arca tersebut telah dicatat pula oleh seorang ahli sejarah bangsa Belanda yang pernah mengunjungi Mojopuro

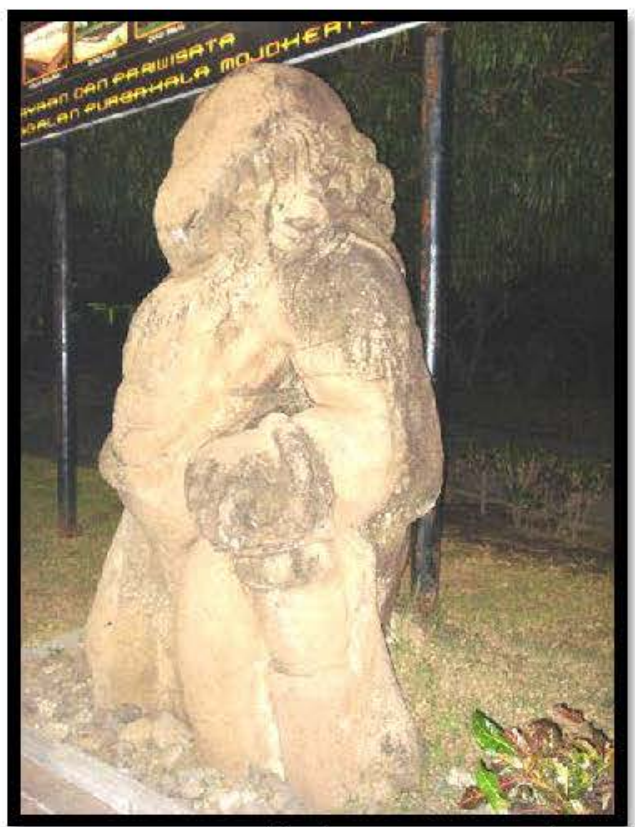

Arca Dwarapala dari Mojopura, di Pusat Informasi Majapahit, Trowulan. Sumber: dok.Balar Yogya Wetan pada tahun 1813, yaitu DR. Vorderman. Setelah itu, DR. Knebel juga membuat laporan tentang keberadaan ketiga patung itu pada tahun 1902 (Widodo, 2004: 130). Arca dwarapala yang masih utuh tersebut, pada tahun 2005 telah dipindahkan oleh Balai Pelestarian Peninggalan Purbakala Jawa Timur dan diletakkan di halaman depan dekat pintu masuk ke Gedung Museum atau Pusat Informasi Majapahit (PIM) di Trowulan di Mojokerto.

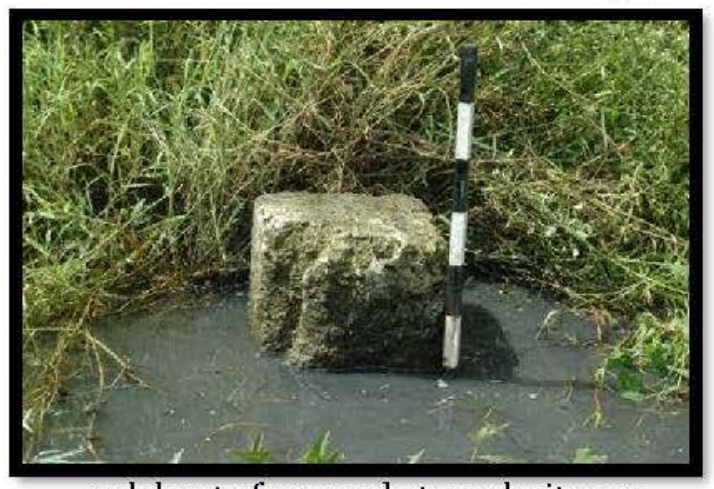

salah satu fragmen batu andesit yang ditancapkan di Situs Gale Gambang sumber: Balar Yogya
Fragmen arca dwarapala yang sudah hancur, sebagian batunya dimanfaatkan oleh pemilik lahan untuk pembuatan pondasi pagar halaman. Arca Budha dengan ukuran dua meter dengan lebar satu meter tidak diketahui lagi keberadaannya. Selain itu, di desa itu pula ditemukan fragmen-fragmen gerabah dan keramik Cina yang tersebar pada radius kurang lebih 100 meter. Temuan-temuan tersebut

diduga merupakan sisa-sisa aktivitas yang pernah terjadi pada masa lalu. 
Pada jarak sekitar kurang lebih dua ratus meter ke arah timur laut dari tempat ditemukannya arca, terdapat suatu tempat yang disebutkan oleh penduduk dengan nama bale kambang atau Gale Gambang. Di tempat ini ditemukan tiga batu berbentuk segi empat panjang yang pada bagian atasnya semakin mengecil. Bagian bawah batu ini terbenam di dalam lumpur di tengah-tengah sawah, sehingga tidak diketahui tinggi seluruhnya, sedangkan lebar batu sekitar $45 \mathrm{~cm}$. Nama Bale Kambang, disebutkan oleh penduduk, karena pada saat Bengawaan Solo banjir, patok-patok batu tersebut tidak tenggelam seluruhnya, bahkan dapat menjadi tanda batas antara sungai dan daratan. Sementara itu nama Gale Gambang, menurut seorang penduduk yang bernama Ahmad Mustofa yang menjabat Kepala Urusan Umum Kelurahan, merujuk pada cerita orang-orang tua, yang mengatakan batu itu merupakan tempat alat-alat musik. Gambang adalah sejenis alat musik gamelan. Lebih lanjut disebutkan, "pada malam hari, sehabis musim hujan, sering terdengar alunan suara musik dari daerah tersebut." Selain itu, daerah tersebut dianggap angker dan tidak sembarang orang berani menjamah dengan seenaknya, misalnya untuk mencari rumput dan bermain-main di atasnya.

Melihat bentuk dan bahan tiga batu tersebut yang terbuat dari batuan andesit, kemungkinan merupakan bekas tonggak untuk mengikat atau menaruh benda tertentu, apalagi sekitar 100 meter di sebelah selatannya, terdapat tambangan atau tempat menyeberang. Tambangan tersebut berfungsi untuk menyeberangkan penduduk dari wilayah Gresik ke wilayah Kabupaten Lamongan. Pada masa lalu, sekitar tahun 1960 - 1980 merupakan tempat penyeberangan dan lalu lintas perdagangan antara dua desa di wilayah tersebut. Pada tahun 1980 pemerintah daerah Gresik membangun jembatan untuk menghubungkan dua wilayah yang terpisah oleh sungai itu. Sejak itulah, penyeberangan sungai tersebut mulai ditinggalkan oleh penduduk dan semakin sepi dari aktivitas penyeberangan. Bersamaan waktu itu pula jumlah tukang sebrang (satang) semakin berkurang dan kini, tinggal tiga orang, antara lain; Edi, Aris dan Ariful. Ketiganya adalah penduduk Desa Mojopura Wetan.

Lebih menarik, sampai saat ini penduduk Mojopuro menamakan jalan menuju ke tempat ditemukannya arca-arca tersebut sebagai Jalan Majapahit, karena mereka yakin itulah jalan menuju ke ibukota Majapahit. Menurut mereka, setelah menyebarang melalui sungai Bengawan Solo, kemudian orang akan melewati pintu gerbang yang dijaga oleh dua arca dwarapala. Dengan mengikuti jalan itu, ia akan sampai ke lbukota Majapahit. Meskipun demikian, masyarakat tidak mengetahui dengan pasti kebenaran cerita itu. Setidaknya, dengan bukti-bukti arkeologis, berupa dua arca dwarapala dengan ukuran cukup besar, fragmen tembikar dan keramik Cina, fragmen batu berbentuk tiang di tepi sungai, serta toponim Gale Gambang (Bale Kambang), Mojopuro terbukti merupakan desa kuna.

Letak Mojopuro yang berada di tepi Bengawan Solo mendukung kemungkinan desa ini menjadi salah satu desa penyeberangan. Beberapa sumber prasasti pada masa Majapahit menyebutkan Bengawan Solo dan 
Sungai Brantas merupakan sungai yang penting. Sungai-sungai tersebut menjadi sarana transportasi pada masa itu selain jalan darat. Jalur sungai menjadi jalur perdagangan yang menghubungkan daerah hulu dengan daerah hilir serta sebagai prasarana penyeberangan antar desa di tepi sungai. Di dalam prasasti disebutkan sejumlah nama desa penyeberangan di seluruh Yawadwipamandala, meskipun sebetulnya nama-nama lebih merujuk pada tempat-tempat di sepanjang Bengawan Solo, Sungai Brantas, dan sungai besar lainnya. Desa-desa yang terletak di pinggir sungai itu di dalam prasasti disebut Naditirapradesa. Desa-desa tersebut mendapat kewajiban menyeberangkan penduduk yang akan melewati sungai menuju seberang untuk berdagang (Soekarto, 1979: 69-71).

\section{TUKANG SEBRANG}

Kehidupan manusia tidak lepas dari pengaruh alam dan lingkungannya. Demikian pula masyarakat Mojopura yang terletak di tepi sungai besar. Dalam rangka pemenuhan kebutuhan hidup, beberapa penduduk Mojopura memilih profesi sebagai tukang sabrang (satang). Profesi tersebut sudah dilakukan sejak dari beberapa generasi sebelumnya, tetapi sejak tahun 1985-an pekerjaan tersebut mulai ditinggalkan, karena tidak ada lagi orang yang menyeberang. Pada saat ini, tinggal tiga orang yang masih menekuni profesi tersebut, jika dahulu mereka menyeberangkan orang/ para pedagang dengan bawaannya berupa bermacam jenis

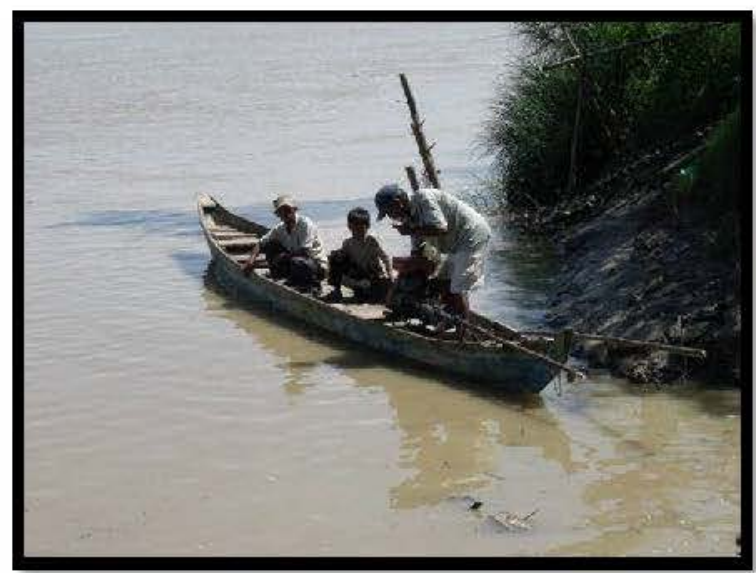

Tukang sabrang dengan perahunya di Mojopuro Sumber: dok.Balar Yogya barang dagangan, saat ini mereka hanya menyeberangkan penduduk antar desa.

Menyeberangkan orang dengan perahu, bukanlah hal yang mudah dan bisa dilakukan oleh setiap orang, karena dalam kegiatan itu ada tanggungjawab moral terhadap keselamatan penumpang yang sepenuhnya ditangan tukang sabrang. Beberapa hal yang digunakan dan cara yang dilakukan tukang sebrang untuk memberikan pelayanan kepada para penumpang, adalah sebagai berikut.

1. Perahu dan peralatan:

- Perahu yang digunakan berukuran panjang 6 meter lebar 1 meter dan tinggi $60 \mathrm{~cm}$. Pada bagian atas gading-gading ditutup dengan anyaman bambu sebagai alas tempat duduk. 
- Tukang sabrang harus merawat perahu secara rutin, terutama pada bagian-bagian yang rawan akibat benturan dengan kayu yang hanyut, khususnya pada musim banjir. Bagian lunas, gading-gading dan dinding perahu perlu mendapat perhatian khusus. la juga harus menyiapkan peralatan dasar, seperti dayung, galah dari bambu/ kayu, tali dan ember untuk menguras air yang masuk ke dalam perahu. Galah biasanya digunakan untuk mendorong perahu dari tebing sungai agar meluncur agak ke tengah sungai. Setelah menjauh dari dermaga, mereka mulai menggunakan dayung untuk menambah kecepatan dan melawan arus sungai. Penggunaan bambu selain sebagai pendorong juga untuk menambatkan sementara perahu setelah sampai di seberang.

2. Cara menempatkan barang dan penumpang

Faktor penting dalam penyeberangan adalah keseimbangan dengan mengatur barang maupun penumpang pada tempat yang disediakan. Barang bawaan penumpang yang berat harus diletakkan pada bagian bawah dan agak di belakang (buritan). Penumpang kemudian menyesuaikan dengan duduk di atasnya menghadap ke depan (haluan). Tukang sebrang duduk di bagian buritan untuk mengendalikan laju perahu. Perahu berukuran kecil ini hanya dapat memuat sekitar empat orang penumpang.

3. Waktu dan cara menyeberang

Penyeberangan dilakukan sejak pagi hari sekitar pukul $06.00 \mathrm{WIB}$, ketika hari sudah cukup terang dan bersamaan waktunya orang berangkat ke pasar dan bekerja. Namun, tentu saja mereka harus memperhatikan kondisi air sungai, jika air pasang atau terjadi banjir, penyeberangan akan ditunda sampai permukaan air sungai kembali normal. Jika terjadi banjir, pengendalian perahu tentu sulit dilakukan, karena derasnya arus. Penyeberangan dilakukan dengan cara melaju melawan arus terlebih dahulu, setelah sampai pada jarak tertentu yang dipandang aman barulah haluan diarahkan ke tempat tujuan.

Pada saat ini beberapa tukang sabrang di daerah Plampang, Mojopuragede, menambahkan mesin tempel pada bagian buritan, sehingga dapat melaju melawan arus dan dapat menyeberangkan penumpang setiap waktu karena tidak tergantung pada musim (air tinggi atau banjir). Perahu yang digunakan biasanya berukuran lebih besar dengan panjang 7,7 meter dan lebar 1,8 meter, bahkan dapat mengangkut dua sepeda motor dengan delapan orang penumpang.

\section{KESIMPULAN}

- Mojopura Wetan diduga sebagai salah satu desa penyeberangan yang pernah ada pada masa Majapahit, seperti ditulis dalam Ferry Charter 1358 Saka yang menyebutkan adanya 77 nama-nama desa 
penambangan, antara lain: Madantĕn, Wringin Wok dan Bajrapura. Nama Bajrapura mungkin berkembang menjadi Mojopura (Wetan), yang juga terletak berdekatan dengan Bedanten (Madanten) dan Kali Wot (Wringin Wok) sekarang.

- Ditemukannya tiga arca dengan ukuran yang relatif besar (dua arca dwarapala dan satu arca Budha) menunjukkan bahwa desa ini merupakan salah satu desa penting, untuk masuk ke ibukota kerajaan.

- Adanya toponim Gale Gambang atau Bale Kambang yang ditandai dengan patok batu, serta keberadaan arca dwarapala, arca Budha dan sebaran fragmen keramik mendukung kekunaan desa tersebut. Selain itu, di desa ini juga berkembang cerita bahwa jalan menuju ke sabrangan hingga ke tempat ditemukannya arca dwarapala, adalah jalan untuk menuju ke Majapahit. Oleh karena itu, sampai saat ini disebut sebagai Gang Majapahit.

- Aktivitas kehidupan sebagai tukang sabrang sudah dilakukan oleh penduduk setempat sejak beberapa generasi. Menurut ingatan mereka setidaknya sudah empat generasi secara turun-temurun. Aktivitas para tukang sabrang tersebut dapat digunakan sebagai bahan analogi, untuk menggambarkan kehidupan tukang sabrang pada masa Jawa kuna (kerajaan Majapahit).

\section{KEPUSTAKAAN}

Atmodjo, K. Sukarto M.M, 1979. Struktur Masyarakat Jawa Kuna pada Jaman Mataram Hindu dan Majapahit. Yogyakarta: Pusat Penelitian dan Studi Pedesaan Kawasan Universitas Gajah Mada.

Daeng, Hans J. 2005. Manusia, Kebudayaan dan Lingkungan, Tinjauan Antropologis. Yogyakarta: Pustaka Pelajar.

Hole, Frank and Robert F. Heizer. 1973. An Introduction to Prehistoric Archaeology 3 nd editions, New York: Holt, Rinehart and Winston Inc.

Pigeuad, TG Th. 1969. Java In The 14th Century. A Study In Cultural History s' Gravenhage: Martinus Nijhoff.

Watson, Patty Jo, Steven A. Le Blanc, Charles L. Redman. 1971. Explanation in Archaeology: An Explicity Scientific Approach. New York: Columbia University Press.

Widodo, Imam Dukut. "Patung Dwarapala di Mojopurawetan", Grissee Tempo Doeloe. Pemerintah Kabupaten Gresik. 